\title{
The Use of Non-Verbal Communication in Supporting the Realization of Brown \& Levinson Politeness Strategies
}

\author{
Inne Nurmalasari ${ }^{\bowtie}$, Januarius Mujiyanto, Henrikus Joko Yulianto \\ Universitas Negeri Semarang, Indonesia
}

\begin{abstract}
Article Info
Article History:

Recived 09 May 2021

Accepted 17 July2021

Published 15

September 2021

Keywords:

Realization, politeness strategies, NVC, classroom interaction

Abstract

One of the prominent issues in pragmatics is politeness. Politeness can manifest in two actions, verbal and non-verbal communication. This study aimed to analyze the lecturer's and the students' non-verbal communication (NVC) in supporting the realization of Brown \& Levinson's politeness strategies in English classroom interaction at Universitas Muhammadiyah Purworejo. This study explains the lecturer's and students' NVC in supporting the realization of bald on record strategy, positive politeness strategy, negative politeness strategy, offrecord strategy, and don't do the face-threatening act (FTA) strategy in English classroom interaction. In this study, the researchers applied qualitative research. The subjects were one English lecturer and students. The objects were the lecturer's and the students' utterances during the English learning process. The methods the researchers used to analyze the data were Brown \& Levinson's (1987) politeness strategies theory and Novinger's (2001) NVC theory. The findings showed that politeness strategies were used by the lecturer and students with the total frequency of 559 times, namely bald on record, positive politeness (dominantly used), negative politeness, off-record, and don't do the FTA (the least used). Besides, in supporting the realization of politeness strategy, the dominantly used methods of NVC were chronemics, kinesics, and vocalic. In conclusion, politeness strategies are crucial in maintaining the relationship and creating a comfortable environment in the EFL classroom. NVC can support performance that cannot be expressed in words.
\end{abstract}




\section{INTRODUCTION}

Communication is the exchange of ideas and information (Richards and Schmidt, 2010). The purpose of communication is to get messages from other people in an unambiguous way. That is, when we are talking with other people we must pay attention to the setting or context of the conversation that includes; with whom, when, and where we talk.

Context is very closely related to culture that certainly is different. It can help learners to establish meaning. It also can influence what to say and how to say it. If a speaker does not understand the audience, then this will make the audience unable to receive messages from the speaker well. Related to this matter, everyone needs to learn pragmatics which is concerned with the study of language that is used in context (Illie and Norrick, 2018).

But here, pragmatics is not able to reach the diversity of contexts caused by cultural differences. Therefore, sociolinguistics is needed here to examine this matter deeply. Sociolinguistics describes how social norms constrain appropriate language use (Illie and Norrick, 2018). The merger between sociolinguistics (sociology and linguistics) and pragmatics is sociopragmatics. Sociopragmatics not only focuses on language but also on the social environment which supports that language.

In classroom interaction, communication between the interlocutors does not just have linguistic competence. Here, communicative competence is also necessary. Social distance can influence communication in classroom interaction, and the lecturer has more power than the students (Carniasih, 2011). Effective communication happens when both verbal and non-verbal messages are synchronous (Ali, 2011). Showing awareness and consideration of another person's face can be called politeness (Yule, 2010). Besides that, politeness refers to strategic conflict avoidance (Leech, 1980). The use of politeness strategies can shorten the distance between lecturer and their students so that the class will be interesting.
The researchers took some previous studies as inspiration and consideration to conducting the study. Some of those studies are studies by Sulu (2015); Jiang (2010); \& Oliveira (2009), who have researched teachers' politeness in the classroom. They found that politeness existed in that EFL classroom. It can help the students have positive feelings towards the lesson, also motivated them to participate more in classes. After that, politeness does promote mutual understanding and harmonious relationships between both teachers and students. Next, politeness does enhance teaching and benefits the students. Politeness does contribute to effective interaction in class.

Next, Agustina and Cahyono (2016); Suhartono et al. (2018); Karimnia and Khodashenas (2017); \& Rahayuningsih et al. (2020) researched teachers students' politeness in the classroom. They showed that maintaining a relationship and creating a comfortable environment in class is crucial. Teachers should be aware of using threatening utterances that could negatively affect their students' selfesteem. These studies brought forth some implications to the students, such as how students speak appropriately to their teachers.

Moreover, studies by Karimi et al. (2012); Bambaeeroo (2017); Butt (2011); Barati (2015), Taleb and Larbi (2018), dealt with the impact of $\mathrm{NVC}$ in the classroom and found that teachers use NVC in the class. It has a positive relationship between the teacher and students. Although it was hard to create that situation, there were suitable solutions. The solution to overcome students' difficulties in oral participation included smiling at them, such as nodding with their heads, after they have performed a speaking task and establishing eye contact with them when participating with their attitudes.

Other studies by Septiana et al. (2018); Panjaitan et al. (2017); Zakaria (2018) researched verbal interaction in the classroom. They found that teaching activities were carried out in two ways between students and the teacher. The teacher used more verbal communication while NVC rather than the 
students. The learning process was carried out with several activities such as games, singing, using teaching tools (television, pictures, and toys), and telling stories in communication to make the students more easily understand what the teacher says.

There are several reasons for choosing this topic. First, in reality, there are some lecturers as a determiner just guided by doing their job, filling in the attendance list, and considering that they have already done their duty. They are unconscious that the teaching and learning process guided by them will bring some influence, also impact on students, especially success in absorbing the learning process. Second, most schools teach English as a foreign language. But, there are some obstacles as the barricade that make the students feel complicated, even hard to master. Many teachers/lecturers do not care about this, because they have no strategies in teaching. Third, long distances between lecturers and students should be avoided, especially by the lecturer. If the relationship between lecturers and students is not close, for example, they feel estranged from each other, it will make the teaching and learning atmosphere less comfortable. Fourth, interpersonal communication is expanding and receiving information explicitly and implicitly that is expressed non-verbally. Sometimes people do not want to convey the true meaning of communication to smooth the conversation. Based on the description above, according to the researchers, it is necessary to know and investigate the lecturer's speech and style or strategy during the learning process in the classroom. The researchers want to know and analyze the use of NVC in supporting the realization of Brown \& Levinson's politeness strategy between lecturers and students in English class interactions at Muhammadiyah University of Purworejo.

This study analyzes the lecturer's and students' NVC in supporting the realization of Brown \& Levinson's politeness strategies in English classroom interaction at UniversitasMuhammadiyahPurworejo. This study explains the lecturer's and students' NVC in supporting the realization of bald on record strategy, positive politeness strategy, negative politeness strategy, off-record strategy, and don't do the FTA strategy in English classroom interaction.

There are several benefits expected from this research. First, this study explains the NVC of lecturers and students in supporting the realization of a bald on record strategy in English class interactions. Theoretically, this finding is helpful for lecturers who did not want to minimize the threat to their students' faces. Practically, this research can help lecturers to convey something directly. Pedagogically, in this study, the bald on record strategy can help lecturers provide clear directions on what students need to do in the learning process.

Second, this recent study explains the lecturer and the students' NVC supporting the realization of a positive politeness strategy in English classroom interaction. Theoretically, the findings are necessary for lecturers to create a good relationship, also allow social relations to be smoother. Practically, this research can help lecturers make students comfortable with themselves, their interest, and their possessions. Pedagogically, this strategy helps lecturers to build closer relationships with students, and get to know each other well enough to make the learning process successful.

Third, this recent study explains the lecturer's and students' NVC supporting the realization of negative politeness strategy in English classroom interaction. Theoretically, the findings are helpful to reducing or avoiding students feeling bad in the classroom process. Practically, this research can help lecturers to minimize coercion when having conversations with their students. Pedagogically, this study may help the lecturers to redress the distance and wariness when teaching in the classroom.

Fourth, this recent study explains the lecturer's and students' NVC in supporting the realization of off-record strategy in English classroom interaction. Theoretically, this finding can help the lecturers' utterances that their use of language with precise meaning has to be 
interpreted indirectly. Practically, this study can help the lecturers avoid the responsibility for some potential to threaten the face when having conversations with their students. Pedagogically, the strategies may help the lecturers to give more than one interpretation about what the lecturers' utterances are.

Fifth, this recent study explains the lecturer's and students' NVC in supporting the realization of don't do FTA strategy in English classroom interaction. Theoretically, this finding of the don't do FTA strategy is simply that the speaker avoids offending the hearer at all. Practically, this study can help the lecturers not to make students feel threatened. Pedagogically, the strategies may help the lecturers to provide some solution to the students' problems about the learning process in classroom interaction without oppressing their students.

\section{METHODS}

In this study, the researchers applied qualitative research. The research was conducted at Universitas Muhammadiyah Purworejo. The subjects were one English lecturer and students. The study used a random sampling technique to select the lecturer. Furthermore, the objects of the study were lecturers' and the students' utterances during the English learning process. In this research, the researchers used kinds of procedures in collecting the data, such as: Preparing the plan at the beginning with choosing University. Then, doing the observation, audio-recording, video-recording, and interview. The researchers observed the lecturer's utterances with their nonverbal interactions acquired by a video recorder, and audio-recorder during the teaching-learning process. After that, the researchers did interviews with both the lecturer and the students. The last is document analysis. The recording was transcribed and analyzed. After collecting the data, the researchers analyzed them based on the theory explored. The data analysis in this research was transcribed, identified, and classified. The researchers chose the theory of Brown \& Levinson (1987), as a basis for analyzing politeness strategies. Novinger's (2001) theory was also added to analyze NVC. After analyzing the data, the researchers concluded and proposed suggestions based on the results. The researchers used the triangulation technique as the step to examine the validity of the data. The researchers used all the basic types of triangulation by Denzin (1973), namely: (1) Data triangulation which includes time, space, person; (2) Researcher triangulation which involves some researchers to investigate the data; (3) Theoretical triangulation that used more than one theory to interpret data; and; (4) Methodological triangulation which used more than one method to collect the data.

\section{RESULTS AND DISCUSSION}

The Lecturer's and Students' NVC in Supporting the Realization of Bald On Record Strategy in English Classroom Interaction

In the bald on record strategy, $\mathrm{S}$ does nothing to minimize threats to H's face (directly without regard to H's face). The situation is when a person directly addresses some expression, such as: ask something, commands, please.

Table 1.The use of NVC in supporting Bald On Record Strategy

\begin{tabular}{|c|c|c|c|}
\hline Turn & Dialogue & NVC & $\begin{array}{l}\text { Bald on } \\
\text { Record }\end{array}$ \\
\hline $\mathrm{L}$ & $\begin{array}{l}\text { Give the real } \\
\text { name! }\end{array}$ & $\begin{array}{l}\text { The lecturer was giving } \\
\text { instructions to the } \\
\text { students during the } \\
\text { zoom meeting in high } \\
\text { pitch voice, he } \\
\text { frowned, with his eyes } \\
\text { turning to students. }\end{array}$ & Strategy 5 \\
\hline $\mathrm{L}$ & $\begin{array}{l}\text { I don't like } \\
\text { it. }\end{array}$ & $\begin{array}{l}\text { The lecturer was } \\
\text { explaining the rules to } \\
\text { the students during the } \\
\text { zoom meeting in } \\
\text { medium-low pitch } \\
\text { voice, with a steady } \\
\text { tempo, and his eyes } \\
\text { seeing to students. }\end{array}$ & Strategy 6 \\
\hline$S$ & $\begin{array}{l}\text { But, I have } \\
\text { to go now, } \\
\text { goodbye } \\
\text { Smith. }\end{array}$ & $\begin{array}{l}\text { The student was } \\
\text { talking in conversation } \\
\text { with the other student } \\
\text { during the zoom } \\
\text { meeting in medium } \\
\text { pitch voice, steady } \\
\text { tempo with her eyes } \\
\text { down. }\end{array}$ & $\begin{array}{c}\text { Strategy } \\
10\end{array}$ \\
\hline $\mathrm{L}$ & $\begin{array}{l}\text { Have a look } \\
\text { at the yes-no }\end{array}$ & $\begin{array}{l}\text { The lecturer was } \\
\text { instructing the students }\end{array}$ & Strategy 2 \\
\hline
\end{tabular}




\begin{tabular}{|c|c|c|c|}
\hline & questions. & $\begin{array}{l}\text { during the zoom } \\
\text { meeting in medium- } \\
\text { high pitch voice, with } \\
\text { his eyes focused on a } \\
\text { handout and also his } \\
\text { eyes turning to } \\
\text { students. }\end{array}$ & \\
\hline $\mathrm{L}$ & $\begin{array}{l}\text { Marcella } \\
\text { mute your } \\
\text { device! }\end{array}$ & $\begin{array}{l}\text { The lecturer was giving } \\
\text { instruction fast to the } \\
\text { student during the } \\
\text { zoom meeting in } \\
\text { medium-high pitch } \\
\text { voice, with his eyes } \\
\text { focused on the student } \\
\text { and he frowned. }\end{array}$ & Strategy 1 \\
\hline $\mathrm{L}$ & Okay, who? & $\begin{array}{l}\text { The lecturer responded } \\
\text { fast to the student } \\
\text { offers in medium pitch } \\
\text { voice, with his eyes } \\
\text { looking in all } \\
\text { directions, his head } \\
\text { moved from side to } \\
\text { side and he frowned. }\end{array}$ & Strategy 8 \\
\hline$S$ & Elya. & $\begin{array}{l}\text { The student responded } \\
\text { to the lecturer's } \\
\text { question directly, in a } \\
\text { medium-pitch voice. }\end{array}$ & $\begin{array}{c}\text { Strategy } \\
11\end{array}$ \\
\hline
\end{tabular}

The conversations are shown in Table I happened when the lecturer and students discussed online class meetings by using the zoom application because of the pandemic situation (covid-19) that requires them to study online every day until an indefinite time.

In the first discussion, based on the data analysis, bald on record strategies were found $7 \%$ or 39 times. The researchers found some utterances used by the lecturer and the students were included in the sub-strategy of politeness strategies theory by Brown \& Levinson (1987). The utterances used by the lecturer, as "Give the real name!" (strategy 5: taskoriented/paradigmatic form of instruction);" I don't like it" (strategy 6: power different between $\mathrm{S}$ and $\mathrm{H}$ ); "Have a look at the yes-no questions" (strategy 2: metaphorical urgency); "Marcella mute your device!" (strategy 1: maximum efficiency); "Okay, who?" (strategy 8 : permission that $\mathrm{H}$ has requested); and; some utterances used by the students, as "But, I have to go now, good-bye Smith" (strategy 10: farewells); "Elya" (strategy 11: offers). Besides, in supporting the action, the researchers also found some expressions used by the lecturer. After that, the students were included in the category of NVC theory by Novinger (2001). The expressions used by the lecturer with the context of the situation of NVC, as: 'He instructed the students in high pitch voice during the zoom meeting. He frowned, with his eyes turning to students'. (kinesic and vocalic); 'He explained the rules to the students in a mediumlow pitch voice, with a steady tempo, and his eyes seeing to students during the zoom meeting'. (kinesic and vocalic); 'He instructed the students in a medium-high pitch voice, his eyes focused on the handout. His eyes turned to students during the zoom meeting'. (kinesic and vocalic); 'He instructed fast to the student in medium-high pitch voice, with his eyes focused on the student and frowned during the zoom meeting'. (kinesic and vocalic); and; 'He responded fast to the student offer in medium pitch voice, with his eyes were looking at all directions, his head moved from side to side and he frowned' (kinesic and vocalic). On the other side, the expressions used by the students, as 'She was talking conversation with the other student during the zoom meeting in medium pitch voice, a steady tempo with her eyes down' (kinesic and vocalic); 'She responded to the lecturer's question directly in medium-pitch voice' (kinesic and vocalic). The data showed that the lecturer does not want to spend much time managing the class. Therefore, he used the direct way to give instructions. Bald on record is one of the strategies used by the speaker who did no attempt to minimize the threat to the hearer's face. Bald on record allows $\mathrm{S}$ and $\mathrm{H}$ to get clarity about the meanings the speaker is trying to convey. However, it also indicates that the lecturer has more power over the students or when one student talked to the other students by using this strategy. Bald on record is crucial to give effective and instruction in the classroom.

\section{The Lecturer's and Students' NVC in Supporting the Realization of Positive Politeness Strategy in English Classroom Interaction}

Positive politeness strategy used in an interaction where $\mathrm{S}$ wants to sacrifice his/her positive face to express closeness and friendliness with showing interest as if $\mathrm{H}$ needs to be respected by the others. 
Table 2.The use of NVC in supporting Positive Politeness Strategy

\begin{tabular}{|c|c|c|c|}
\hline Turn & Dialogue & NVC & $\begin{array}{c}\text { Positive } \\
\text { politeness }\end{array}$ \\
\hline $\mathrm{L}$ & $\begin{array}{l}\text { So, we have } \\
\text { plus-minus } \\
\text { one I think to } \\
\text { nineteens. }\end{array}$ & $\begin{array}{l}\text { The lecturer was seeing } \\
\text { the students during the } \\
\text { zoom meeting in } \\
\text { medium pitch voice } \\
\text { with his eyes turning to } \\
\text { students. }\end{array}$ & $\begin{array}{c}\text { Strategy } \\
12\end{array}$ \\
\hline $\mathrm{L}$ & $\begin{array}{l}\text { Mmm, okay } \\
\text { I'm... I'm still } \\
\text { waiting for the } \\
\text { slide. }\end{array}$ & $\begin{array}{l}\text { The lecturer explains } \\
\text { faster with his eyes } \\
\text { turning to students. }\end{array}$ & Strategy 7 \\
\hline $\mathrm{L}$ & $\begin{array}{l}\text { You got join } \\
\text { such kind of } \\
\text { University or } \\
\text { kind of collage } \\
\text { or courses in } \\
\text { the class? }\end{array}$ & $\begin{array}{l}\text { The lecturer responded } \\
\text { to the student during } \\
\text { the zoom meeting in } \\
\text { medium-high pitch } \\
\text { voice with his eyes } \\
\text { turning to students, } \\
\text { with moving his head. }\end{array}$ & Strategy 3 \\
\hline $\mathrm{S}$ & Thank you. & $\begin{array}{l}\text { The student responded } \\
\text { to the lecturer's } \\
\text { question in high } \\
\text { pitched voice. }\end{array}$ & Strategy 2 \\
\hline $\mathrm{L}$ & $\begin{array}{l}\text { Can you see } \\
\text { the slide? Can } \\
\text { you see the } \\
\text { slide? Amalia } \\
\text { and others? }\end{array}$ & $\begin{array}{l}\text { The lecturer was seeing } \\
\text { the students during the } \\
\text { zoom meeting and } \\
\text { asking in high pitch } \\
\text { voice, the tempo was } \\
\text { faster than before, he } \\
\text { frowned, with his eyes } \\
\text { turning to students. }\end{array}$ & Strategy 5 \\
\hline$S$ & $\begin{array}{lr}\text { Wow, same } \\
\text { with } \\
\text { Nabila. }\end{array}$ & $\begin{array}{l}\text { The student was } \\
\text { talking to the other } \\
\text { student in a medium } \\
\text { pitch voice, with her } \\
\text { eyes turning to the } \\
\text { screen. }\end{array}$ & $\begin{array}{c}\text { Strategy } \\
14\end{array}$ \\
\hline $\mathrm{L}$ & $\begin{array}{l}\text { Why did you } \\
\text { joining } \\
\text { English } \\
\text { program? } \\
\text { Rather than } \\
\text { other } \\
\text { programs in } \\
\text { UMP? }\end{array}$ & $\begin{array}{l}\text { The lecturer was seeing } \\
\text { the students during the } \\
\text { zoom meeting in } \\
\text { medium-high pitch } \\
\text { voice with his eyes } \\
\text { turning to students. }\end{array}$ & $\begin{array}{c}\text { Strategy } \\
13\end{array}$ \\
\hline $\mathrm{L}$ & $\begin{array}{l}\text { Okay, I think } \\
\text { maybe you got } \\
\text { a problem } \\
\text { with the } \\
\text { audio. You } \\
\text { just chat eee in } \\
\text { group or } \\
\text { private with } \\
\text { me, okay. }\end{array}$ & $\begin{array}{l}\text { The lecturer was seeing } \\
\text { the students during the } \\
\text { zoom meeting in } \\
\text { medium pitch voice, } \\
\text { with his eyes turning to } \\
\text { the screen. }\end{array}$ & Strategy 6 \\
\hline $\mathrm{L}$ & $\begin{array}{l}\text { But, but I } \\
\text { always feel } \\
\text { younger, right } \\
\text { in every } \\
\text { situation. }\end{array}$ & $\begin{array}{l}\text { The lecturer was } \\
\text { explaining to the } \\
\text { students during the } \\
\text { zoom meeting in a } \\
\text { medium-low pitch } \\
\text { voice with his eyes } \\
\text { looking at the students, } \\
\text { his head turned right- } \\
\text { left. }\end{array}$ & $\begin{array}{c}\text { Strategy } \\
11\end{array}$ \\
\hline $\mathrm{S}$ & $\begin{array}{l}\text { Of course. I'll } \\
\text { be there to see } \\
\text { your } \\
\text { performances. }\end{array}$ & $\begin{array}{l}\text { The student promises } \\
\text { to the other student in } \\
\text { a high-low pitch voice. }\end{array}$ & $\begin{array}{c}\text { Strategy } \\
10\end{array}$ \\
\hline $\mathrm{S}$ & you, & The student agreed to & Strategy 4 \\
\hline
\end{tabular}

\begin{tabular}{cl}
\hline Cipo... & $\begin{array}{l}\text { the other student in a } \\
\text { low-pitched voice. }\end{array}$ \\
\hline
\end{tabular}

In the second discussion, based on the data analysis, positive politeness strategies were used $63 \%$ or 352 times. It means that the lecturer tried to satisfy the students' positive face. It also means that the lecturer tried to build a close relationship with the students (Brown \& Levinson, 1978). The researchers found some utterances used by the lecturer and the students were included in the sub-strategy of politeness strategies theory by Brown \& Levinson (1987). The utterances used by the lecturer, as "So, we have plus-minus one I think to nineteens" (strategy 12: include both $\mathrm{S}$ and $\mathrm{H}$ in the activity); "Mmm, okay I'm... I'm still waiting for the slide" (strategy 7: presuppose, assert common ground, raise); "You got join such kind of University or kind of collage or courses in the class?" (strategy 3: intensify interest to $\mathrm{H}$ ); "Can you see the slide? Can you see the slide? Amalia and others?" (strategy 5: seek agreement (repetition, safe topics)); "Why did you joining English program? Rather than other programs in UMP?" (strategy 13: give/ask for reasons); "Okay I think maybe you got a problem with the audio. You just chat eee in group or private with me, okay" (strategy 6: avoid disagreement); "But, but I always feel younger, right in every situation" (strategy 11: be optimistic); and; some utterances used by the students, as "Thank you" (strategy 2: exaggerate (sympathy, interest, approval with $\mathrm{H})$ ); "Wow, same with me Nabila" (strategy 14: assume/assert reciprocity); "Of course. I'll be there to see your performances" (strategy 10: offer, promise); "See you, Cipo..." (strategy 4: use 'in group' identity markers (jargon, dialect, addressed forms, slang)). Besides, in supporting the action, the researchers also found some expressions used by the lecturer. Also, the students were included in the category of NVC theory by Novinger (2001). The expressions used by the lecturer with the context of the situation of NVC, as 'He was seeing the students during the zoom meeting in medium pitch voice with his eyes turning to students' (kinesic and vocalic); 'He explains faster with his eyes turning to students' 
(chronemics, kinesic and vocalic); 'He responded to the student during the zoom meeting in medium-high pitch voice with his eyes turning to students, by moving his head' (kinesic and vocalic); 'He was seeing the students during the zoom meeting in high pitch voice, the tempo was faster than before, he frowned, with his eyes turning to students' (kinesic and vocalic); 'He was seeing the students during the zoom meeting in mediumhigh pitch voice with his eyes turning to students' (kinesic and vocalic); 'He was seeing the students during the zoom meeting in medium pitch voice with his eyes turning to screen' (chronemics, kinesic and vocalic); ' $\mathrm{He}$ was explaining to the student during the zoom meeting in medium-low pitch voice with his eyes looking at the students, his head turned right-left (kinesic and vocalic). On the other side, the expressions used by the students, as: 'She responded to the lecturer's question in highpitched voice'. (kinesic and vocalic); 'She talked to the other student in a medium pitch voice, with his eyes turning to the screen'. (kinesic and vocalic); 'She promises to the other student in a high-low pitch voice' (kinesic and vocalic); 'She agreed to the other student in a low pitch voice' (kinesic and vocalic).

\section{The Lecturer's and Students' NVC in Supporting the Realization of Negative Politeness Strategy in English Classroom Interaction}

A negative politeness strategy occurs when people want to have freedom of action that is unobstructed, also unrestricted. Besides, it means a redressive action addressed to the addressee's negative face.

Table 3.The use of NVC in supporting Negative Politeness Strategy

\begin{tabular}{cllr}
\hline Turn & \multicolumn{1}{c}{ Dialogue } & \multicolumn{1}{c}{ NVC } & $\begin{array}{c}\text { Negative } \\
\text { Politeness }\end{array}$ \\
\hline L & $\begin{array}{l}\text { Okay, so The lecturer was } \\
\text { everyone please }\end{array}$ & Strategy 8 \\
& seeing the students & \\
because I need to & meeting the zoom \\
see your face eee & medium pitch \\
clearly, so...so voice, with his eyes \\
give me easiness turning to students \\
for knowing and with smiling.
\end{tabular}

remembering you one by one.

L $\begin{aligned} & \text { Oouchh... taking } \\ & \text { so long, sorry... }\end{aligned}$
seeing the students
during the zoom
meeting, and he
said in low pitch
voice and he
frowned.

In the third discussion, based on the data analysis, negative politeness strategies were used $23 \%$ or 126 times. The researchers found some utterances used by the lecturer and the students were included in the sub-strategyof politeness strategies theory by Brown \& Levinson (1987). The utterances used by the lecturer, as "Okay, so everyone please open your video because I need to see your face ee clearly, so... so give me easiness for knowing and remembering you one by one" (strategy 8: state about the FTA as the general rule); "Oouchh... taking so long, sorry..." (strategy 6: apologies); "Okay Amalia please" (strategy 1: be conventionally indirect); "Can I ask the question? Can you see my slide here?" (strategy 2: question, hedge); "It should...it should be Haning. If Haning it's okay, Haning first. Haning and Syifa. Haning, can you get the words? Have to send Haning actually" (strategy 4: minimize imposition); and; some utterances used by the students, as "Yes, sir" (strategy 5: give deference). Besides, in supporting the action, the researchers also found some expressions used by the lecturer. Also, the 
students were included in the category of NVC theory by Novinger (2001). The expressions used by the lecturer with the context of the situation of NVC, as: 'He was seeing the students during the zoom meeting in medium pitch voice with his eyes turning to students with a smiling'. (kinesic and vocalic); 'He saw the students during the zoom meeting in low pitch voice and frowned'. (kinesic and vocalic); 'He responded to the student's request in low pitch voice'. (kinesic and vocalic); 'He asked the students in medium-high pitch voice and frowned'. (kinesic and vocalic); He talked to the student in a medium-low pitch voice with his eyes looking at the screen with his eyebrow pulled up, by nodding his head while giving an explanation and a little smile'. (kinesic and vocalic). On the other side, the student used the expression in the class, such as 'She responded to the lecturer question fast' (kinesic and vocalic). The data showed that it indicates that the lecturer barely gives deference to his students, and also it indicates that the students barely give deference to the lecturer and the other students. For the lecturer, this is understandable. That was because he dominates the classroom, and he has higher power and status than his students.

\section{The Lecturer's and Students' NVC in Supporting the Realization of Off-Record Strategy in English Classroom Interaction}

The off-record strategy enables students to convey the intention by avoiding the responsibility of doing the FTA. It also leaves $\mathrm{H}$ to decide the interpretation.

Table 4.The use of NVC in supporting OffRecord Strategy

\begin{tabular}{|c|c|c|c|}
\hline Turn & Dialogue & NVC & $\begin{array}{c}\text { Off- } \\
\text { Record }\end{array}$ \\
\hline $\mathrm{L}$ & $\begin{array}{lr}\text { "Never } & \text { trouble } \\
\text { trouble, } & \text { till } \\
\text { trouble } & \text { troubles } \\
\text { you". } & \end{array}$ & $\begin{array}{l}\text { The lecturer was } \\
\text { talking to the students } \\
\text { in a high-medium pitch } \\
\text { voice with his eyes } \\
\text { looked down, and } \\
\text { screen, the head was } \\
\text { pulled back and then } \\
\text { back again. }\end{array}$ & $\begin{array}{c}\text { Strategy } \\
9\end{array}$ \\
\hline $\mathrm{L}$ & $\begin{array}{l}\text { You } \\
\text { trouble. }\end{array}$ & $\begin{array}{l}\text { The lecturer was } \\
\text { talking to the students } \\
\text { in a medium pitch }\end{array}$ & $\begin{array}{c}\text { Strategy } \\
8\end{array}$ \\
\hline
\end{tabular}

\begin{tabular}{|c|c|c|c|}
\hline & & $\begin{array}{l}\text { voice with his eyes } \\
\text { looked down, and } \\
\text { screen, little smile. }\end{array}$ & \\
\hline $\mathrm{L}$ & $\begin{array}{l}\text { The first trouble } \\
\text { is Noun. The } \\
\text { second trouble is } \\
\text { Verb. The third } \\
\text { trouble is a } \\
\text { Noun. Theeee } \\
\text { one okay the } \\
\text { fourth trouble is } \\
\text { a Verb again. } \\
\text { Yes, anyone? } \\
\text { Can give the } \\
\text { meaning or even } \\
\text { by giving } \\
\text { example? }\end{array}$ & $\begin{array}{l}\text { The lecturer was } \\
\text { explaining to the } \\
\text { students in high- } \\
\text { medium pitch voice } \\
\text { with his eyes looking } \\
\text { down \& screen, with } \\
\text { one eyebrow pulled up } \\
\text { and little smile, the } \\
\text { head was pulled back } \\
\text { and then back again, } \\
\text { he frowned slightly. }\end{array}$ & $\begin{array}{c}\text { Strategy } \\
3\end{array}$ \\
\hline $\mathrm{L}$ & $\begin{array}{l}\text { So how..how } \\
\text { eee }\end{array}$ & $\begin{array}{l}\text { The lecturer was } \\
\text { talking to the students } \\
\text { in a high-pitched voice. }\end{array}$ & $\begin{array}{c}\text { Strategy } \\
15\end{array}$ \\
\hline $\mathrm{L}$ & $\begin{array}{l}\text { Okay, thank } \\
\text { you. Maybe } \\
\text { something } \\
\text {....eee problem } \\
\text { with the } \\
\text { connection or } \\
\text { the kind of } \\
\text { device in yours. }\end{array}$ & $\begin{array}{l}\text { The lecturer was } \\
\text { talking to the student } \\
\text { in a low-pitched voice } \\
\text { with his eyes looking at } \\
\text { the screen with his } \\
\text { eyebrow pulled up and } \\
\text { little smile, the head } \\
\text { was pulled left \& right. }\end{array}$ & $\begin{array}{c}\text { Strategy } \\
12\end{array}$ \\
\hline L & $\begin{array}{ll}\text { Okay, } & \text { two } \\
\text { thousand } & \text { and } \\
\text { nineteen. } & \text { Two } \\
\text { thousand } & \text { and } \\
\text { nineteen. } & \end{array}$ & $\begin{array}{l}\text { The lecturer responded } \\
\text { to the student with eyes } \\
\text { looking towards the } \\
\text { right above, with the } \\
\text { body was pulled back } \\
\text { and then back again. }\end{array}$ & $\begin{array}{c}\text { Strategy } \\
6\end{array}$ \\
\hline $\mathrm{L}$ & $\begin{array}{l}\text { Aaa, I think you } \\
\text { get the problem } \\
\text { with the audio } \\
\text { device. }\end{array}$ & $\begin{array}{l}\text { The lecturer was } \\
\text { talking to the student } \\
\text { with eyes focusing on } \\
\text { the screen, in medium- } \\
\text { low pitch voice and } \\
\text { faster tempo, he } \\
\text { frowned slightly. }\end{array}$ & $\begin{array}{c}\text { Strategy } \\
14\end{array}$ \\
\hline L & $\begin{array}{l}\text { Okay, what's } \\
\text { wrong with your } \\
\text { audio Nisa U1? }\end{array}$ & $\begin{array}{l}\text { The lecturer was asking } \\
\text { the student with eyes } \\
\text { focusing on the screen, } \\
\text { in medium-high pitch } \\
\text { voice. }\end{array}$ & $\begin{array}{c}\text { Strategy } \\
4\end{array}$ \\
\hline $\mathrm{L}$ & Isna? & $\begin{array}{l}\text { The lecturer was asking } \\
\text { the student with eyes } \\
\text { focusing on the screen, } \\
\text { his head looking right- } \\
\text { left, in medium-high } \\
\text { pitch voice, he } \\
\text { frowned. }\end{array}$ & $\begin{array}{c}\text { Strategy } \\
1\end{array}$ \\
\hline $\mathrm{L}$ & $\begin{array}{l}\text { Elya, ouch Elya } \\
\text { iya, I didn't see } \\
\text { your face } \\
\text { because no } \\
\text { video Elya. }\end{array}$ & $\begin{array}{l}\text { The lecturer was } \\
\text { answering the student } \\
\text { in a high-low pitch } \\
\text { voice, he frowned with } \\
\text { focusing on the screen, } \\
\text { he starts sitting } \\
\text { forward, then backs } \\
\text { away with a slight } \\
\text { smile. }\end{array}$ & $\begin{array}{c}\text { Strategy } \\
2\end{array}$ \\
\hline $\mathrm{L}$ & $\begin{array}{l}\text { Okay. } \\
\text { Mul... }\end{array}$ & $\begin{array}{l}\text { The lecturer was } \\
\text { talking to the student } \\
\text { in a low-pitched voice } \\
\text { with a little laugh, he } \\
\text { sits with his body } \\
\text { pulled forward slightly } \\
\text { and focusing on the } \\
\text { screen. }\end{array}$ & $\begin{array}{c}\text { Strategy } \\
11\end{array}$ \\
\hline $\mathrm{L}$ & $\begin{array}{l}\text { You are going to } \\
\text { greeting and }\end{array}$ & $\begin{array}{l}\text { The lecturer was } \\
\text { explaining to the }\end{array}$ & $\begin{array}{c}\text { Strategy } \\
7\end{array}$ \\
\hline
\end{tabular}




\begin{tabular}{ll}
\hline closing. & $\begin{array}{l}\text { students in a medium- } \\
\text { low pitch voice, he } \\
\text { pulled his head to the } \\
\text { left. }\end{array}$ \\
\hline
\end{tabular}

In the fourth discussion, off-record strategies were used $7 \%$ or 41 times. It indicates that the lecturer enables his students to decide the interpretation when he gave instructions. The researchers found that some utterances used by the lecturer were included in the sub-strategy of politeness strategies theory by Brown \& Levinson (1987). The utterances used by the lecturer, as "Never trouble trouble, till trouble troubles you" (strategy 9: use metaphors); "You never trouble" (strategy 8: be ironic); "The first trouble is Noun. The second trouble is Verb. The third trouble is a Noun. Theeee one okay the fourth trouble is a Verb again. Yes, anyone? Can give the meaning or even by giving example?" (strategy 3: presuppose); "So how...how eee" (strategy 15: be incomplete, use ellipsis); "Okay thank you. Maybe something .....eee problem with the connection or the kind of device in yours" (strategy 12: be vague); "Okay, two thousand and nineteen. Two thousand and nineteen" (strategy 6: tautologies); "Aaa I think you get the problem with the audio device" (strategy 14: displace H); "Okay, what's wrong with your audio NisaUl?" (strategy 4: understate); "Isna?" (strategy 1: give hints); "Elya, oouchhElyaiya, I didn't see your face because no video Elya" (strategy 2: give association clues); "Okay. Eee... Mul..." (strategy 11: ambiguous); "You are going to greeting and closing" (strategy 7: contradictions). Besides, in supporting the action, the researchers also found some expressions used by the lecturer. Those included in the category of NVC theory by Novinger (2001). The expressions used by the lecturer with the context of the situation of NVC, as 'He was talking to the students in a high-medium pitch voice with his eyes looked down, and screen, the head was pulled back and then back again' (kinesic and vocalic); 'He was talking to the students in a medium pitch voice with his eyes looked down, and screen, little smile' (kinesic and vocalic); 'He was explaining to the students in high-medium pitch voice with his eyes looking down on the screen, with one eyebrow pulled up and little smile, the head was pulled back and then back again, he frowned slightly' (kinesic and vocalic); 'He was talking to the students in a high pitch voice' (kinesic and vocalic); 'He was talking to the student in a low pitch voice with his eyes looking at the screen with his eyebrow pulled up and little smile, the head was pulled left \& right' (cronemics, kinesic and vocalic); 'He responded to the student with eyes looking towards the right above, with the body was pulled back and then back again' (kinesic and vocalic); 'He was talking to the student with eyes focusing on the screen, in medium-low pitch voice and faster tempo, he frowned slightly' (cronemics, kinesic and vocalic); 'He was asking to the student with eyes focusing on the screen, in medium- high pitch voice' (cronemics, kinesic and vocalic); 'He was asking to the student with eyes focusing on at the screen, his head looking right-left, in medium-high pitch voice, he frowned' (kinesic and vocalic); 'He was answering the student in a high-low pitch voice, he frowned with focusing on the screen, he starts sitting forward, then backs away with a slight smile' (kinesic and vocalic); 'He was talking to the student in a low pitch voice with a little laugh, he sit with his body pulled forward slightly and focusing on the screen' (kinesic and vocalic); 'He was explaining to the student in a medium-low pitch voice, he pulled his head to the left' (kinesic and vocalic).

The Lecturer's and Students' NVC in Supporting the Realization of Don't Do the FTA Strategy in English Classroom Interaction

This strategy shows that people, in general, are faced with two choices, namely whether they want to do an FTA or not, and it has consequences as well. 
Table 5.The use of NVC in supporting Don't Do the FTA Strategy

\begin{tabular}{clll}
\hline Turn & \multicolumn{1}{c}{ Dialogue } & NVC & $\begin{array}{c}\text { Don't } \\
\text { Do the } \\
\text { FTA }\end{array}$ \\
\hline $\mathrm{L}$ & $\begin{array}{l}\text { Can...can, can I When the lecturer } \\
\text { get one student to asking the } \\
\text { be my partner? students, one of }\end{array}$ \\
& $\begin{array}{l}\text { Can I get one the students did } \\
\text { student to be my not answer but she } \\
\text { partner now? } \\
\text { raising her hand. }\end{array}$ \\
\hline $\mathrm{S}$ & $\begin{array}{l}\text { Silent with raising } \\
\text { a hand. }\end{array}$ \\
\hline
\end{tabular}

In the fifth discussion, based on the data analysis, the researchers found that don't do the FTA strategy was used $0,2 \%$ or 1 time. It was done by a female student when the lecturer asked a question. After that, the student used don't do the FTA strategy to respond lecturer's question. When the lecturer asked all students in the class, said, "Can..can, can I get one student to be my partner? Can I get one student to be my partner now?". It was supported by the context of the situation of NVC. All students keep silent. But, one student did not answer but just raised her hand. It indicates that the student used don't do the FTA strategy. It also indicates that the student rarely gave an indirect message to the lecturer.

The researchers presented some relevant previous studies conducted by other researchers. Based on the discussions above, it can be concluded that there were similarities and differences between the researchers' study and the previous studies. The similarities among all the previous studies with the researchers' study were the topic (verbal communication, politeness strategies, and NVC in class). On the other side, the differences were the title, the aims of the study, the data analysis, the significance of the study, the findings and discussions, and also the conclusions and suggestions. The researchers' study entitled 'The use of NVC in supporting the realization of Brown \& Levinson politeness strategies in classroom interaction at UniversitasMuhammadiyahPurworejo'. It is also subdivided into five questions: how do the lecturer's and students' NVC support the realization of bald on record strategy, positive politeness strategy, negative politeness strategy, off-record strategy, and 'don't do the FTA strategy' in English classroom interaction. If compared with the sixty previous studies, the researchers thought that this research will be more complete, because all previous studies, just research 4 strategies from Brown \& Levinson (1987), whereas, Brown \& Levinson's (1987) have 5 strategies on politeness. For example, a study conducted by Adel et al. (2016). It was about Iranian EFL learners in a class blog. It analyzed politeness strategies of bald on-record, positive politeness, negative politeness, and offrecord strategies in posts. Based on this explanation, the researchers were looking for gaps based on sixty articles that share several topics in common, which have been reviewed in Chapter II, namely in the section on review of previous studies. Here, the researchers tried to research almost the same topic but examine the topic further than what the previous studies did. The researchers examined the five parts of the politeness strategies, namely bald on record strategy, positive politeness strategy, negative politeness strategy, off-record strategy, and also don't do the FTA strategy used by lecturers and students in the English classroom interaction. Besides that, the aims are to analyze the lecturer's and students' NVC in supporting the realization of Brown \& Levinson's politeness strategies in English classroom interaction at UniversitasMuhammadiyahPurworejo. It also answered the five parts of questions: explain the lecturer's and students' NVC in supporting the realization of bald on record strategy, positive politeness strategy, negative politeness strategy, off-record strategy, and don't do the FTA strategy in English classroom interaction. In addition, in the current study, the researchers used methods to analyze the data. The data analysis in this research was transcribed, identified, and classified. The researchers chose Brown \& Levinson's (1987) theory to support this study as the basis to analyze politeness strategies. This analysis will reveal NVC used by the lecturer to teach his students in classroom interaction. Novinger's (2001) theory was also used to analyze NVC. After analyzing the data, the researchers concluded and proposed suggestions based on the results. The previous 
studies also chose some theories to analyze their data, such as a study conducted by Afdaliah et al. (2017). This study focuses on identifying the kinds of NVC that used by the teachers at SMAN 1 Pamboang in teaching English as a foreign language. To analyze the data, they used Miles and Huberman's (1994) theory. Those are data reduction data display, and conclusion drawing. Based on the explanations above, here, the researchers examined verbal (politeness strategies) and NVC. All of this communication is very supportive in daily communication, especially between students \& lecturers, who have different powers. Most of the previous studies and almost all of them raised one topic. That topic is about politeness strategies (verbal) or just NVC. Therefore, the researchers thought that this research will be more challenging and make some research findings because verbal and NVC are very crucial in communicating and interconnecting. The researchers chose some related theories in previous studies as to the references which can help the researchers in analyzing data. It was because the researchers discussed some parts which have the same topic as that of the previous studies. Next, for the significance of the study, the authors explained and classified benefits theoretically, practically, and pedagogically to see the benefits of the study. Since this research differs from other researches on the same topic, the result, conclusion, and suggestions will differ, too. The suggestions were intended for future researchers; English lecturers also EFL learners; and; pedagogical implications.

\section{CONCLUSIONS}

First, bald on record strategies was found $7 \%$ or 39 times. There were seven sub-strategies realized, namely: maximum efficiency; metaphorical urgency for emphasis; taskoriented/paradigmatic form of instruction; power difference between $\mathrm{S}$ and $\mathrm{H}$; permission that $\mathrm{H}$ has requested; farewells; and offers. Here, the lecturer and the students mostly used NVC, namely kinesics and vocalic. Second, positive politeness strategies were used $63 \%$ or 352 times.
There were eleven sub-strategies realized, namely: exaggerate; intensify interest to $\mathrm{H}$; use 'in group' identity markers; seek agreement; Avoid disagreement; presuppose, assert common ground, raise; offer, promise; be optimistic; include both $\mathrm{S}$ and $\mathrm{H}$ in the activity; give/ask for reasons; and; assume/assert reciprocity. Here, the lecturer and the students mostly used NVC, namely chronemics, kinesics, and vocalic. Third, negative politeness strategies were used $23 \%$ or 126 times. There were eleven sub-strategies realized, namely: be conventionally indirect; question, hedge; minimize imposition; give deference; apologies; and state about the FTA as the general rule. Here, the lecturer and the students mostly used NVC, namely kinesics, and vocalic. Fourth, offrecord strategies were used $7 \%$ or 41 times. There were eleven sub-strategies realized in this research, namely: give hints; give association clues; presuppose; understate; tautologies; contradictions; be ironic; use metaphors; ambiguous; be vague; displace $\mathrm{H}$; and be incomplete, use ellipsis. Here, the lecturer and the students mostly used NVC, namely kinesics, and vocalic. Fifth, don't do the FTA strategy was used $0,2 \%$ or 1 time. Here, the one student used NVC, namely: kinesics.

\section{REFERENCES}

Adel, S. M. R., Davoudi, M., \&Ramezanzadeh, A. (2016). A qualitative study of politeness strategies used by Iranian EFL learners in a class blog. Iranian Journal of Language Teaching Research, 4(1), 47-62.

Afdaliah, N., Halim, A., \& Sultan.(2017). Teacher's nonverbal communication in EFL classroom.State University of Makassar Research Repository.

Agustina, S. \&Cahyono, B. Y. (2016). Politeness and power relation in EFL classroom interactions: A study on Indonesian learners and lecturers. International Journal of Language and Linguistics, 3(2), 92-100.

Ali, S.A.M. (2011, May 5-7). The use of nonverbal communication in the classroom 
(Paper presentation).1st International Conference on Foreign Language Teaching and Applied Linguistics, Sarajevo.

Bambaeeroo, F., \&Shokrpour, N. (2017). The impact of the teachers' non-verbal communication on success in teaching. Journal of Advances in Medical Education \& Professionalism,5(2). 51-59.

Barati, L. (2015). The impact of eye contact between teacher and student on L2 learning.Journal of applied linguistics and language research, 2(7), 222-227.

Brown, P. \& Levinson, S. C. (1987). Politeness: Some universals in language usage. Cambridge University Press

Butt, M. N. (2011).Impact of non-verbal communication on students' learning outcomes.Sarhad University Research Repository.

Carniasih, N. P. S. E. (2011). The politeness at English classroom interaction and its implications toward English teachinglearning in Wearness Education Center Bali.Udayana University Research Repository.

Denzin, N. K. (1973). The research act: A theoretical introduction to sociological methods. Transaction Publisher.

Illie, C., \&Norrick, N. R. (2018).Pragmatics and its interfaces. John Benjamin Publishing.

Jiang, X. (2010).A Case study of teacher's politeness in EFL class. Journal of Language Teaching and Research, 1(5), 651-655.

Karimi, M., Dabaghi, A., \&Tabatabaei, O. (2012).The impact of nonverbal communication on Iranian young EFL learners' attitudes and understanding of lexical items. BELT Journal, 3(2), 188203.

Karimnia, A. \&Khodashenas, M. R. (2018). Patterns of politeness in teacher-student interaction: Investigating an academic context. The Journal of Applied Linguistics ad Applied Literature: Dynamics and Advances, 5(1), 69-87.
Leech, G. N (1980).Explorations semantics and pragmatics. John Benjamin B.V.

Novinger, Tracy. (2001). Intercultural communication: A practical guide. (1st ed). University of Texas Press.

Oliveira, A. W. (2009). "Kindergarten, can I have your eyes \& ears?" Politeness and teacher directive in inquiry-based science classrooms. Cult Stud of SciEduc, 4, 803846.

Panjaitan, T. N., Suryani, I., Wanasari, S., \&Charunisak, S. (2017). Interaction of verbal communication of the teacher from the Philippines in the teaching activity for nursery II students at the Singapore International School, Medan. International Journal of Scientific \& Technology Research, 6(07), 33-40.

Rahayuningsih, D., Saleh, \&Fitriati (2020). The realization of politeness in EFL teacherstudents classroom interaction. English Education Journal,10(1), 85-93.

Richards, J. C. \& Schmidt, R. (eds). (2010). Longman dictionary of language teaching and applied linguistics. Pearson Education Limited.

Septiana, A., Hamzah, \&Amri, Z. (2018).Verbal interaction between male and female teachers and their students in the English class. Journal of Advances in Social Science, Education and Humanities Research, 301, 513-516.

Suhartono, Nurkamto, J., Sumariam.,\&Marmanto, S. (2018). Politeness and impoliteness in the directive: A study on the studentslecturers interaction. Advances in Social Science, Education and Humanities Research, 280, 327-333.

Sulu, A. (2015). Teacher's Politeness in EFL Class. International online journal of education and teaching (IOJET), 2(4).216-221.

Taleb, M. \&Larbi, I. (2018). The impact of teacher's non-verbal communication on students' speaking performance: The case study of first-year EFL students at 
Tlemcen University. University of Tlemcen Research Repository.

Yule, G. (2010). The study of language.Cambridge University Press.

Zakaria, B. N. A. (2018). Verbal politeness strategies used by students to teachers in their communication at

PesantrenRahmatan Lil Alamin.

Universitas Islam RadenRahmat Malang

Research

Repository. 